\title{
Editorial
}

\section{Mobilizações de migrantes e refugiados: as lutas pela visibilidade e pelo reconhecimento}

A multiplicação de movimentos populares de luta e resistência em nível mundial é sinal do exacerbado crescimento do número de pessoas que são - e têm consciência de serem - prejudicadas ou violentadas pela ordem hegemônica assimétrica em nível local ou planetário. Para além do tradicional - e ainda atual - conflito entre capital e trabalho, novos movimentos sociais surgem em resposta à depredação do meio ambiente, à discriminação ou menosprezo dos direitos fundamentais de determinados grupos sociais como mulheres, LGBT, povos autóctones, minorias, entre outros. Ainda que frequentemente silenciados pela imprensa internacional, é suficiente citar os movimentos de protesto e reivindicação de Chiapas (1994), de Seattle (1999), a assim chamada "Primavera árabe" (2010), o movimento dos Indignados na Espanha (2011), os recentes e maciços protestos na França e no Brasil (2016).

Em meio a tudo isso, chama a atenção também a "primavera" das mobilizações de migrantes e refugiados. Trata-se de atos de protesto e reivindicação que, embora bastante heterogêneos em termos de atores, interlocutores, objetivos e mediações, visam fundamentalmente à busca pela visibilidade e pelo reconhecimento.

As lutas pela visibilidade questionam abertamente a assim chamada "clandestinidade voluntária", evidenciando como a grande maioria dos deslocados almeja e procura uma presença regular e transparente no país de chegada. A invisibilidade, que gera atávicas fobias e políticas securitárias, é induzida, imposta, não fruto de uma escolha.

Por outro lado, as lutas pelo reconhecimento visam, antes de tudo, reivindicar o direito de serem reconhecidos como "sujeitos de direitos" nos países de origem, trânsito e chegada. Estas lutas colocam em discussão abordagens meramente economicistas, que, com frequência, categorizam os recémchegados como meros "instrumentos de trabalho", as visões assistencialistas, que neutralizam a subjetividade e a agency dos migrantes, e os enfoques etnocêntricos, que desconsideram ou menosprezam os direitos culturais de indivíduos e povos, bem como os benefícios da interação intercultural. 
O ativismo de migrantes e refugiados, portanto, além de reivindicações pontuais, objetiva desmistificar imaginários tipificados em relação aos deslocamentos populacionais, questionando abordagens reducionistas e apontando para o estabelecimento de relações simétricas pautadas no respeito dos direitos humanos.

Ademais, é bom ressaltar que os movimentos sociais de reivindicação ou, mais simplesmente, as ações espontâneas de protesto, individuais ou coletivas, já constituem em si atos de visibilidade, afirmações de presença, irrupções na esfera pública de seres humanos que se autorreconhecem como sujeitos políticos. Em outros termos, a visibilidade e o reconhecimento são instrumentos de luta e, ao mesmo tempo, seus objetivos. As mobilizações expressam, materializam e performatizam desejos, aspirações e utopias.

A mobilidade não é suficiente e deve ser complementada pela mobilização. A mobilidade permite ultrapassar as fronteiras geográficas, mas é a mobilização que derruba as fronteiras socioculturais da exclusão, da discriminação, da não-cidadania. E é justamente ao tema do ativismo, das mobilizações, dos movimentos sociais de migrantes e refugiados que é dedicado o dossiê da REMHU número 48.

No primeiro artigo do dossiê, Valentine Le Borgne de Boisriou, após apresentar casos de violência institucional contra migrantes indocumentados na França (as "redadas" e os centro de detenção), analisa as ações reativas dos sans papiers, que se mobilizam mediante greves de fome, marchas e ocupações. De acordo com a autora, os migrantes indocumentados manifestam sua agency dando visibilidade à própria debilidade, à própria condição de vítima, e, desta forma, transformam o sentimento de vergonha em instrumento de pressão política.

Amarela Varela Huerta, por sua vez, analisa o ativismo de migrantes em um país, o México, caracterizado pela migração de trânsito e de retorno. Focando a ação do Movimiento Migrante Mesoamericano, Varela evidencia como o objetivo dessa rede, que atua em termos de incidência política, lobby legislativo e ação direta, é garantir direitos para todos ("todos los derechos para todos") e, sobretudo, promover o reconhecimento, por parte da sociedade mexicana, de dois interlocutores: os mexicanos que vivem no exterior e os transmigrantes centroamericanos. Nesse contexto, o ativismo visa à superação do racismo social e institucional que permeia o país.

A partir de uma perspectiva etnohistórica transnacional, Bela FeldmanBianco aborda as mobilizações de transmigrantes brasileiros e suas repercussões em relação à agenda migratória portuguesa e brasileira. Essas mobilizações, que tiveram origem em Portugal, assumiram um alcance geográfico cada vez mais amplo, contaram com o gradativo apoio de numerosos segmentos sociais - 
academia, grupos de inspiração religiosa, partidos políticos, governo brasileiro, entre outros - e desencadearam um amplo movimento de reivindicação que contribuiu na conscientização acerca da diáspora brasileira e da necessidade de uma reformulação da anacrônica legislação imigratória no Brasil.

María Luz Espiro, Sonia Voscoboinik e Bernarda Zubrzycki se debruçam sobre as estratégias individuais e coletivas que migrantes senegaleses e afrodescendentes na Argentina utilizam a fim de reivindicar direitos em um contexto de rígido controle estatal e de racismo institucional. Analisando dois casos específicos, as autoras sublinham as variáveis que podem promover ou inibir a agência desses migrantes, uma agência que é sempre condicionada por fatores subjetivos, biográficos, contextuais e culturais.

Ao tema do "caporalato" (contratação ilegal de trabalhadores) e aos atos de protesto de trabalhadores migrantes agrícolas no sul da Itália é dedicado o artigo de Angelo Scotto. Segundo o autor, que reflete a partir de dois estudos de caso, as mobilizações de trabalhadores migrantes são exceções, mas podem ocorrer sob determinadas condições, alcançando resultados expressivos. O estudo dessas condições específicas, coadunado por um forte compromisso político contra o caporalato, pode contribuir para empoderar os trabalhadores estrangeiros.

Annalisa Lendaro aprofunda a reflexão sobre manifestações de protesto de migrantes na ilha fronteiriça de Lampedusa, no Sul da Itália, a fim de evidenciar os fatores que possibilitam processos emancipatórios. Partindo da abordagem agambiana sobre o Estado de Exceção, a autora infere que, apesar de inferiorizados, explorando uma conjuntura favorável, grupos de migrantes possuem as potencialidades de agir enquanto sujeitos políticos (being political) e lutar contra leis consideradas injustas - no caso, os Acordos de Dublin.

Finalmente, Mara Pieri apresenta um estudo sobre o movimento UndocoQueers, que surgiu em 2011 nos EUA, com o objetivo de focar as interseções entre o ser queer e o ser indocumentado. Após caracterizar o movimento, a autora analisa a série online "Undocumented and awkward", evidenciando a mútua fecundação entre as reivindicações queer e as lutas pela plena cidadania dos imigrantes irregulares. Trata-se de um exemplo significativo e original de uma forma de ativismo pela arte (Artivism), um autêntico "ato de cidadania", na acepção de Engin Isin.

Na seção Artigos, Victoria Prieto, Sofía Robaina e Martín Koolhaas analisam a inserção laboral de imigrantes recentes, retornados e estrangeiros no Uruguai, levando em conta a comparação com os nativos e as variáveis de país de origem, tempo de presença e gênero. De acordo com os autores, a população estrangeira pesquisada encontra mais dificuldade na inserção no mercado de 
trabalho em comparação com a autóctone não migrante, além de sofrer mais com a informalidade e a sobrequalificação.

Alessandra Ciurlo, Diana Couto-Mármora e Mónica Santagata abordam a emigração de jovens mulheres colombianas para Buenos Aires. De acordo com as autoras, a procura pela emancipação da família e do contexto cultural, tido como conservador e patriarcal, é uma das motivações veladas do deslocamento. As migrantes pesquisadas buscam uma "justa distância" que garanta a própria autonomia e, ao mesmo tempo, que permita a manutenção de relações com parentes e amigos do país de origem.

Julie Lima de Pérez, por sua vez, desenvolve um estudo sobre as políticas antitráfico e antimigração presentes em Portugal e Espanha. Apesar de análogas, essas políticas de prevenção, proteção e punição suscitam diferentes percepções e repercussões pela diversa maneira como são aplicadas nos dois países.

Finalmente, Camila Escudero estuda as redes sociais transnacionais a partir de um grupo de mulheres brasileiras residentes em Chicago, EUA, ressaltando como elas conseguem vivenciar experiências de protagonismo, autonomia e empoderamento mediante a organização de eventos artísticos e festividades relacionadas ao país de origem.

Na seção Relatos e Reflexões, Lidia Maggi reflete sobre as pessoas em mobilidade enquanto chaves hermenêuticas para a compreensão da Bíblia, um livro escrito e contado desde a perspectiva dos migrantes. Já Hannah Waisman e Giulianna Serricella apresentam uma reflexão sobre suas experiências de Consultoras do ACNUR em entrevistas com solicitantes de refúgio e refugiados no Estado do Rio de Janeiro/Brasil.

A seção Resenhas Teses e Dissertações encerra o número da revista com uma resenha de María Del Carmen Villarreal Villamar do livro A invenção da brasilidade. Identidade nacional, etnicidade e políticas de imigração de Jeffrey Lesser.

Desejamos a todas e todos uma boa leitura.

Roberto Marinucci (editor-chefe da REMHU) 